\title{
РОЗДІЛ ІІ.
}

\section{ІМПЕРСЬКI ІСТОРИЧНІ МІФИ \\ В СУЧАСНІЙ УКРАЇНСЬКІЙ \\ ІСТОРІОГРАФІЇ ТА ХУДОЖНІЙ ЛІТЕРАТУРІ}

DOI https://doi.org/10.36059/978-966-397-233-6-6

Борис Драмарецький

\section{Процес творення радянського міфобачення у 20-30-х рр. XX ст. \\ The process of creating Soviet myth-vision in the 1920-1930}

The article examines the process of instilling Bolshevik myth-vision in Ukrainian society, the main ideas of which were laid down in the 1920s. The relevance of the study is due to the fact that the majority of the contemporary population of Ukraine continues to be psychologically in the Soviet socio-cultural space, which is actively used by opponents of Ukrainian statehood in information wars. Post-communist ideologues continue to cultivate established myths, based on a common historical past in a single territorial, ideological, informational and culturological space. And only by removing the imposed model of myth-vision, the country can choose its path of development and become a strong state, which is an urgent need of contemporary Ukrainian society. The purpose of the article is to reveal the technologies of creation and the principles of implantation the main Soviet myths used by the Bolsheviks to control the population. The research methodology consists in the use of interdisciplinary, culturological, political science and historical methods, which has allowed to determine the main elements of the Bolshevik socio-cultural space management for the formation of the worldview of the population. Conclusions. Thus, in the early 1920s, an all-encompassing ideology was imposed in order to form an absolute dependence of society on the party leadership. Its main task was the formation of a new type of man - the "builder of communism", which was characterized by: intolerance of any other point of view, fear of government, irresponsibility and unwillingness to work, inertia (both political and economic), ignorance and incompetence to defend their rights and freedoms, etc. The proletariat, which had no education, was committed to the 
proclaimed ideals, professed the idea of "deprive and divide", and believed in the promise of rapid success, was proclaimed the ruling class. Others (if they were not physically destroyed) were considered secondary. To overcome the "relics of the past" - tsarism, capitalism, Christianity, etc. (in other words, the previous government, predecessors) and to construct a "happy future", new mechanisms were created: a "new religion" was created from "communism" with a corresponding pantheon of gods, saints, heroes, temples and holidays. And complete control over public organizations and according child-raising had catastrophic consequences at the genetic level. The Soviet mentality developed a kind of love for poverty, a negative attitude towards wealth and underestimation of the value of their work, because poor people are needed only by representatives of the real authority those who control the economy and financial flows. This created an idea of free benefits (medicine, education, housing, etc.) given by the government. Thus, Soviet myths shaped the slavish psychology of human dependence on the state, which was reflected in the worldview that still exists to some extent today.

Сьогодні значна кількість населення України продовжує психологічно перебувати в радянському соціокультурному просторі. I хоча з моменту проголошення Акту незалежності пройшло майже 30 років, суспільство лише пробуджується, змінюючи свою ментальність, звільняючись від насаджених моделей поведінки та радянських міфів. Така зацикленість на старих ілюзорних стереотипах пояснюється не лише вкоріненими уявленнями, а й тим, що в інформаційних війнах нині противники української державності активно використовують радянську пропаганду та продовжують культивувати створені нею міфи, спираючись на спільне історичне минуле в єдиному територіальному, ідеологічному, інформаційному та культурологічному просторі під назвою “Радянський Союз” (в минулому “Російська імперія").

Наголосимо, що основні уявлення більшовицького світосприйняття були закладені ще у 20-х роках XX ст., адже саме в цей період суспільству було нав'язане більшовицьке міфобачення ${ }^{1}$, яке передавалося наступним радянським поколінням лише з незначною корекцією. Головним завданням стало створення людини нового

${ }^{1}$ Міфобачення - це відхід від реальності та сприйняття реалій життя скрізь призму нав'язаних ідеології, міфів, які далекі від дійсності - авт. 
типу - “будівника комунізму”. Такі особи “позбавлялися” індивідуальності, а їхнє життя підпорядковувалося єдиній меті - досягненню різнопланових (на які вказували партійні вожді - aвт.) завдань (Борисенко М., 2004, с. 61-63). Наслідком цього стало формування радянського менталітету, для якого характерні: нетерпимість до будь-якої іншої, альтернативної точки зору, окрім “єдино вірної” - комуністичної, беззахисність і страх перед представниками влади, безвідповідальність та небажання працювати (до чого призвела “зрівнялівка” та заниження оплати праці), бюрократія та нерозуміння того, що державні посадовці утримуються на податки населення, інертність (як політична, так і економічна), незнання та невміння відстоювати свої конституційні права та свободи та ін. "Радянські міфи і стереотипи живуть і процвітають у сучасній Україні повсюди, своїм корінням вони сягають російських імперських міфів, не дуже закамуфльованих під радянські" (Зашкільняк Л., 2015, с. 21), - наголошує український історик Леонід Зашкільняк. I лише позбувшись нав'язаної комуністичними та посткомуністичними ідеологами моделі міфобачення, країна може досягти реальної незалежності, обрати свій шлях розвитку і стати сильною державою, що є нагальною потребою для сучасного українського суспільства.

Метою статті є розкриття основних радянських міфів, провідних принципів та технологій їхнього творення та насадження, якими користувалися більшовики у 1920-х рр. для управління населенням.

Останнім часом значно посилилася увага науковців до процесу творення більшовицької міфології, її впливу на суспільну свідомість з метою формування “радянської людини”. Зокрема, проблемам міфології в сучасній свідомості, світоглядної орієнтації населення, радянської ідентичності та їі впливу на формування сучасних суспільних стереотипів посткомуністичної України присвячена значна кількість робіт українських філософів та культурологів (Попович М., 1998, с. 57-68; Модавська Т., 2013, с. 38-40; Нікітенко К., 2016, с. 14). В історичних дослідженнях важливими стали: особливості моделі національної пам'яті, репрезентовані історіографічним дискурсом другої половини 1920-х років (Буряк Л., 2012, с. 3-7); проблеми соціальної 
ідентичності, історичної пам'яті та історичних знань у сучасній українській історіографії (Зашкільняк Л., 2015, с. 17-19; 2016, с. 103-106); нав'язування методами пропаганди та масового терору неприродного соціально-економічний ладу - спотвореного світу комунізму - майже усім народам колишньої Російської імперії (Кульчицький С., 2016; Гриневич В.А., Лисенко О.Є., Даниленко В.М., Кульчицький С.В., 2004; Митрофаненко Ю., 2016; Горенко О., 2014).

Однак, поза увагою залишилися певні питання створення більшовицької системи світосприйняття та технології зруйнування, підміни або замовчування існуючих уявлень про досконале суспільство, пролетаріат, турботу держави та свободу людини в процесі нав'язування комуністичного світобачення.

Насильнецьке насадження пролетарського світогляду розпочалося одночасно із захопленням влади та означало потужну ідеологічну пропаганду з метою управління населенням в інтересах певного угрупування (більшовицького), що бажало встановити своє панування за будь-яку ціну та контролювати "підкорених”, занурюючи їх у своє інформаційне поле. Це означало цілковиту руйнацію існуючих уявлень, понять, символів, віри, традицій, міфології, народних свят, а в разі неможливості - їхню підміну, перекручування або замовчування.

Взявши за основу традиційний менталітет російського населення (відоме “за веру, царя и Отечество”), більшовики, використовуючи всю потужність державного апарату та наявних технологій, спробували їх повністю замінити. До цього додамо жорстку нетерпимість до будь-кого, хто був не згоден та виявляв “інакомислення": від навітів і виселення до фізичного знищення людини і таврування усіх їі близьких та родичів. Йдеться не лише про “ворожі" класи - поміщиків і буржуазію, а й про інтелігенцію, яка “прийняла” революцію. Згадаймо хоча б трагічні долі, переслідування та замовчування творчого доробку Миколи Куліша (“П’єса 97”), Миколи Хвильового (“Я Романтика”), Павла Тичини (“Вітер з України”), Івана Багряного (“Тигролови” та “Сад Гетсиманський”), Василя Барки (“Жовтий князь”), Олександра Довженка (“Щоденник”) та ін. Все це, дивлячись через "рожеві окуляри” пропаганди, більшість суспільства, 
покликана в “новый мир, который мы построим”, не помічала або, підпадаючи під вплив пропаганди, вимагала негайного знищення разом з усіма, на кого вказувала більшовицька партія.

Ця “комуністична релігія” потребувала беззаперечної віри, що грунтувалася на сприйнятті будь-яких ідей або доктрин як абсолюту, без жодних доказів. Адже віра сліпа, бо відключає свідомість. Віруючі “швондери” та “шарікови" 1 страшні саме своїм фанатизмом та неспроможністю не лише зрозуміти, а й навіть вислухати іншу позицію. Жодні факти та аргументи на таких людей не діють, вони не спроможні до критичного аналізу. Їх досить легко ввести в оману, і це прекрасно розуміли більшовицькі вожді.

Однак міфотворення ідеологів комунізму, на противагу зовнішньому офіційному запереченню основних релігійних канонів, нівелювання образів святих і мучеників, за своїми технологіями було засноване на тих самих положеннях і засадах, основними з яких були:

- $\quad$ віра в творення ідеального суспільства, де не буде гнобителів та пригнічених;

- роль месії, пророка та духовного лідера (відводилася виключно більшовицькій партії та її вождям);

- зосередженість повноти влади в руках більшовицької номенклатурної еліти;

- нав'язування ілюзорного (міфологічного) світобачення в усіх сферах життя громади;

- примус усіх без винятку прошарків суспільства діяти як єдиний, запрограмований на певні дії механізм (звідси прагнення до систематичного проведення військових парадів, демонстрацій, лінійок, суботників тощо).

${ }^{1}$ Див: Булгаков М. Собачье сердце. (Під час читання Михайлом Булгаковим уривків із Собачого серця на літературних зборах "Никитинских субботников" 7 та 21 березня 1925 р. агент ОДПУ охарактеризував повість так: «вещь написана во враждебных, дышащих бесконечным презрением к Совстрою тонах». Повість була заборонена і вийшла лише у 1968 р. в Лондоні та Франкфурті. А в СРСР вона вперше була надрукована у 1987 р. - Булгаковская энциклопедия. URL: http://www.bulgakov.ru/s/dogheart/) 
Отже, комуністичне міфобачення, заперечуючи віру в Бога ("релігія - опіум для народу"), впроваджуючи антирелігійну й антицерковну кампанію аж до фізичного знищення духовенства та пограбування церков, створило нову ілюзорну систему світосприйняття. При цьому багато церковних канонів, ритуалів, образів більшовиками було просто перенесено з християнства в нову модель маніпулювання свідомістю мас.

Новою місією ілюзорного раю, звісно ж, стала керівна каста партія більшовиків. Саме вона “тримала" у своїх руках усю повноту влади - від політичної до економічної й ідеологічної, “пронизуючи" усі сфери громадського та особистого життя. Служінню тоталітарному режиму були підкорені усі механізми регулювання суспільного життя. Створювалися “великі" та "малі" свята нової релігії, про які, подекуди, й зараз ностальгує чималий відсоток населення пострадянських країн): 7 листопада, 23 лютого, 8 березня, 1 травня і т. п. Були також засновані й своєрідні “храми” нової релігії - палаци жовтневої революції, будинки Леніна, інститути марксизму-ленінізму, кафедри історії КПРС та ін. Мистецтво та література того часу активно пропагували і несли в маси не “добре та вічне”, а те, на що “дала добро" цензура панівної партійної верхівки.

Комуністичні пропагандисти виконували свою роботу надзвичайно активно. Уже в 1920-х роках було проведено безліч лекцій з комуністичного виховання, побудовано багато хат-читалень, створено агітбригади, куточки пропаганди 3 обов'язковим “пантеоном нових богів": Маркса, Леніна, Сталіна та “ликами” нових святих: Щорса, Дзержинського, Луначарського, Петровського, Артема та ін. Так, відомий український філософ, академік НАН України Мирослав Попович вказує, що «“культи осіб” Леніна і Сталіна були елементами міфології тоталітарного режиму, невіддільними від його політичної структури».

Наслідком цього стало те, що більша частина суспільства дійсно змінила своє світосприйняття (стала “віруючою”), адже міфобачення “нового порядку” з успіхом заміняло та дозволяло не помічати пануюче насильство, безправ'я і репресії. Тож розглянемо основні міфи докладніше. 
Міф про досконале суспільство або створення раю на землі: “Весь мир насилья мы разрушим / До основанья, а затем / Мы наш, мы новый мир построим..."

Рушійною силою нової віри став давно відомий міф про досконале суспільство матеріально забезпечених громадян із рівними правами, можливостями самостійного необмеженого вибору, де завжди панує мир і доброчесність. Тож авторитарно-тоталітарний режим, впроваджений “комуністичними менеджерами”, скористався технологією підміни існуючих християнських уявлень про рівність та рай: “Верблюдові легше пройти через голчине вушко, ніж богатому в Боже Царсто ввійти” (Матвея 19:24) та “Блаженні вбогі духом, бо їхнєє царство небесне” (Матвея 5:3). Більшовики розпочали свою діяльність з експропріації та націоналізації, розуміючи рівність як суцільну бідність та злиденність населення. Це також означало фізичне знищення багатих, адже матеріально забезпечена людина - незалежна людина, яка автоматично перетворювалася на ворога тоталітарного режиму. Тому й почалася боротьба, у першу чергу, проти дворян, поміщиків, буржуазії та представників церкви. А потім продовжилася вже й проти селянства. Рушійною їі силою став люмпенізований прошарок суспільства - пролетаріат.

Прекрасно розуміючи, що будь-яка людина навряд чи може мріяти про жебрацтво, більшовики всіляко намагалися замінили й християнську віру про рай на своє міфобачення, тобто комунізм, де всі в майбутньому будуть духовно (ідейно) та матеріально багатими - "від кожного за здібностями, кожному за потребами". Йшлося про те, що комуністична свідомість сама по собі буде спонукати людину докладати максимум зусиль до праці для суспільства, і при цьому вона передбачає безкоштовність споживання такої кількості товару, якаїй необхідна. А виходячи 3 цього постулату, нав'язувалася ілюзія про необхідність безкоштовно працювати в ім'я світлого майбутнього, на “благо народу", “благо країни” та інші “блага", при цьому забуваючи про самого себе та свою родину. Поширюючи міф будівництва “світлого майбутнього”, влада нав'язувала населенню думку про необхідність єдиного "трудового пориву", трудового ентузіазму і вводила понаднормову та понадурочну роботу, обов'язкову 
участь у комуністичних суботниках (недільниках) та трудових тижнях. Навіть частини Червоної армії переводилися на становище трудових армій. Результатом цього стало катастрофічне заниження вартості оплати праці та перетворення населення на рабів. Адже якщо людина працює безкоштовно (йдеться про прямий примус - від ідеологічного до фізичного), а оплата праці забезпечує лише елементарні потреби, необхідні для її фізичного виживання - харчування, одягу та проживання, то така людина нічим не відрізняється від раба.

До цього додамо й фактичну залежність усього населення від держави. Мова йде не лише про селян-кріпаків. Система залежності та контролю різного ступеня існувала повсюди. Це й прикріплення до підприємств, прописка і т. д. Тож можемо стверджувати, що наслідком реалізації “будівництва комуністичного раю” стало перетворення населення усієї країни на державних рабів.

Натомість сама людина мала жити не реальним життям, а заради “світлого майбутнього”. Адже командна економіка задовольняла потреби суспільства лише на рівні виживання, який був встановлений компартійно-радянським керівництвом. 3’явилася навіть псевдонаука про “соціалістичне ціноутворення”, пов'язана із маніпулюванням цінами (так звані “ножиці цін”). Населенню розповідали про велич країни, в якій виплавляється більше металу, видобувається більше вугілля і т. д., ніж будь-де, однак кінцевим споживачем цих трудомістких і екологічно шкідливих галузей був воєнно-промисловий комплекс. А зростання економіки жодним чином не позначалося на добробуті суспільства.

Комунізм намагався відібрати сьогодення людини заради ілюзорного (міфологічного) щастя для того, щоб захопити існуюче і в подальшому також продовжувати забирати існуюче заради наступного майбутнього і так до безкінечності. Відтак, покращення відкладалося на невизначений термін. Робилося це ж, звичайно, у власних інтересах комуністичних ідеологів за рахунок населення. Згадаймо хоча б величезний відрив між усіма рівнями життя (матеріального, соціального та ін.) номенклатури і пересічної людини. Йдеться не лише про соціальні верстви, проти яких вони боролися, а й про пролетаріат, який був проголошений гегемоном - новоствореним міфологічним героєм. 
Міф про гегемонію пролетаріату: "Кто был никем, тот станет всем"

Разом з впровадженням ідеї “класової диктатури пролетаріату як необхідного перехідного рівня до знищення класових відмінностей взагалі" (Маркс К., 1955, с. 91) створюється міф про пролетаріат як узагальнюючий образ "гегемона суспільства". Як і будь-яка попередня формація (рабовласницька, феодальна, капіталістична) була лише сходинкою до комунізму, так і пригнічені класи (раби, кріпаки, робітники) мали стати рушійною силою на шляху до формування безкласового (понад-класового) суспільства. При цьому відбулося жонглювання такими поняттями, як "робітничий клас" та “пролетаріат", за якого перше замінили другим, де меншість стала визначним для більшості, адже йшлося не про весь робітничий клас, а про люмпен-пролетаріат, безграмотний, що не мав майна, якому “немає чого втрачати, крім власних ланцюгів". I уже від його імені почали виступати більшовицькі лідери.

Вони проголосили пролетаріат панівним класом, потреби якого мали визначати подальший шлях розвитку країни і суспільства в цілому. Чому саме пролетаріат? Тому що ані дворянство, ані буржуазія (підприємці), ані духовенство, ані інтелегенція, ані навіть селянство їх підтримати не могли. Не могли їх підтримати й висококваліфіковані робітники-майстри, які отримували гідну заробітну платню. Організовані відсічі мешканців робітничих кварталів проти більшовицького панування прокотилися територією всієї України. Наприклад, робітники Єлисаветграду в 1918 р. заявили, що будуть захищатися до останнього набою, що вони відійшли від політики, але не бажають підкорятися злочинцям. "Місто залишилося без влади, і населення саме мусить захищати своє майно й життя від зазіхань злих людей, що користаються з моменту" (Митрофаненко Ю., 2016).

Адже менталітет цих суспільних верств суттєво різнився від основних положень більшовизму. Очевидно, що не лише заможних, а й людей, які мали приватну власність або отримували гідну заробітну платню, мало цікавив більшовицький рай у майбутньому. Вони жили щасливо вже сьогодні та чогось досягли тут і зараз. Окрім того, матеріально забезпечена людина - це 
незалежна особистість, а для тоталітарного режиму незалежні люди були загрозою і навіть ворогами. Вони чинили спротив більшовицькому пануванню, захищаючи свій спосіб життя, а поширена ідеологами пропаганда про масову підтримку більшовицької влади робітниками виявилася міфом.

Саме тому пролетаріат стає інструментом для захоплення влади. Тому що, по-перше, людьми, які не мають освіти, простіше маніпулювати; по-друге, пролетаріату була притаманна абсолютна відданість проголошеним ідеалам (згадаймо, як під час громадянської війни відбувалося знищення навіть найближчих родичів за політичними переконаннями); по-третє, віра в обіцянки успіху; по-четверте, низи суспільства було легше очолити.

При цьому більшовицькі ідеологи постійно навіювали пролетаріату міф - уявлення про їхню авангардну роль. I на цьому грунті розвивалося так зване пролетарське чванство - почуття вседозволеності й безкарності. Наприклад, були випадки, коли робітники без усяких на те підстав били фахівців, інженерів та директорів. Отже, у другій половині 20-х рр. XX ст. з'являється новий тип пролетаря-хулігана, що живе у важких умовах та веде майже жебрацьке існування це “свій хлопець" з робочим номером та партбілетом у кишені (Панін С., 2003, с. 140-145; 2009, с. 139-141), якому притаманні соціальна розпуста та низький рівень освіти (Трудовая правда, 1926).

Наголосимо, що для психології люмпенізованих верств суспільства, які намагалися, не дивлячись ні на що, штурмовими методами якомога швидше вирватися з труднощів, було близьким світобачення “відібрати й поділити” та “форсоване соціалістичне будівництво”. Тож збільшення чисельності пролетаріату, основною ознакою якого була відсутність власності та абсолютна відданість проголошеним гаслам, надавало можливості більшовицькому керівництву отримати абсолютну владу та зміцнити свою соціальну базу, впроваджувати політику суспільного прогресу, під яким розумілося цілковите економічне панування. Таким пануванням стала політика “воєнного комунізму". 
Міф про свободу в СРСР: "Я другой такой страны не знаю, / Где так вольно дышит человек".

Процес утвердження більшовиків в Україні початку 20-х рр. $\mathrm{XX}$ ст. розпочався із демагогічних заяв про демократичні принципи та свободи: слова, совісті, віросповідання та повагу до національно-культурних потреб населення. Однак, мета була зовсім іншою - сформувати органи контролю за суспільним та національно-культурним життям і прискорити процес централізації, оскільки комуністична партія України фактично була такою лише за назвою і сприймалася як іншородний елемент на тлі українського суспільства (Нікітенко К., 2016, с. 14). Відомий історик Станіслав Кульчицький наголошує, що "вожді більшовицької фракції російських соціал-демократів здобули популярність у народних низах завдяки популістській демагогії, винайшли таку робітничо-селянську державу, у якій робітники та селяни не мали права голосу, а потім методами пропаганди та масового терору створили неприродний, існуючий тільки в їхніх головах соціально-економічний лад" (Кульчицький С., 2016). Розглянемо реалізацію деяких із свобод та прав громадян в СРСР:

Свобода слова реалізовувалася утвердженням монополії офіційної ідеології та створенням органів цензури. Починаючи з кінця 1918 р., в Україні створюються різноманітні структури 3 метою поширення більшовицької пропаганди, проведення політичної роботи і популяризації комуністичної влади та видання, спрямовані проти усіх "ворогів радянської влади" антиукраїнські (буржуазно-націоналістичні), антирелігійні і т. д. Серед них: Бюро преси при Тимчасовому робітничо-селянському уряді України для "правильного направлення газетної інформації” (Культурне будівництво в Українській РСР, 1959, с. 26), Українське Центральне агентство 3 розповсюдження друкованих творів, Центральне видавниче бюро при відділі освіти більшовицького уряду України, яке контролювало друк видань, декрет "Про створення Народного комісаріату радянської пропаганди" і т. д., а також організація власних партійних видавництв для перевидання російських пропагандистських брошур, створення мережі хат-читалень. 
Вийшла також низка різноманітних заборон з метою "недопущення” будь-якої іншої точки зору. І цьому сприяла цензура. Ще 1919 р. в Україні було створено Редакційно-видавничу колегію, яка керувала всією видавничою справою і мала "вирішувати питання про необхідність випуску в світ того чи іншого твору"1. Наприкінці 1920 р. Наркомат освіти України створив спеціальне управління - Головпросвіту, яка мала, крім усього іншого, здійснювати функції цензури. Згодом, в середині 1922 р. в його складі було створено Центральне управління у справах друку, яке займалося виключно цензурою.

Право на створення та існування громадських організацій означало їх “більшовизацію” та цілковитий контроль. Найбільші з них однозначно перетворювалися у напівпартійні. Особлива увага приділялася профспілкам і комсомолу. IX з'їзд РКП(б) (березень-квітень 1920 р.) відкинув принцип незалежності профспілок і вказав, що вони мають бути одним з основних апаратів держави, керівництво якими здійснюється комуністичною партією, а соціальна роль зводила їхню діяльність до “школи комунізму”. Отже, радянські профспілки не лише цілковито контролювалися більшовиками, а й стали одним з рупорів поширення ідеології. 31918 р. організаційно і політично оформився комсомол, який завжди перебував під керівництвом партії та якому відводилася роль кадрового резерву. Дещо пізніше була створена й піонерія за зразком різноманітних скаутських організацій, метою якої було виховання дітей цілковито відданих комуністичним ідеалам, а головне - більшовицьким вождям та партії. Тому значна увага приділялася військово-патріотичному вихованню, адже ефективність тоталітарної пропаганди на дітей була найбільшою. Якщо доросла людина сприймає світ критично, то дитина все сприймає “на віру". 3 дітей можна було виховати Павку Карчагіна або Павліка Морозова, їх можна було використовувати для роботи (наприклад, в колгоспах або для охорони колгоспного майна), а також при здійсненні політичних кампаній - писати доноси на “ворогів народу",

${ }^{1}$ Коммунистическая партия Украины в резолюциях и решениях, съездов, конференций и пленумов ЦК. Т. 1. 1918-1941. Киев, 1976. С. 58. 
куркулів, шкідників та ін. Такому вихованню сприяло й видавництво “Молода гвардія” при ЦК ВЛКСМ, засноване 1922 р., що друкувало такі журнали, як: “Мурзилка”, “Сельская молодежь”, “Техника-молодежи”, “Юный натуралист”, “Молодая гвардия”, “Вокруг света”, газета “Пионерская правда”. Усі ці дитячі журнали були орієнтовані на радянську дійсність, відповідно до лінії офіційної пропаганди (“Чиж” и “Ёж”. 2015).

Для інших громадських організацій - культурних, наукових, спортивних, оборонних - також визначався критерій їх місця у всеосяжній державній системі ідеологічного виховання комуністичного суспільства, яка "розсмоктувала" або ставила під контроль горизонтальні зв’язки між людьми (навіть сімейні або релігійні), наскрізь “прошивала" суспільство побудованими на засадах “демократичного централізму” вертикалізованими структурами: компартійними, комсомольськими, радянськими, профспілковими, громадськими (Кульчицький С., 2016).

Свобода пересування проіснувала лише кілька років та знайшла своєрідну заміну. Декларативні заяви про відміну дореволюційної паспортної системи закінчилися 1918р. із запровадженням загальної трудової повинності та уведенням “тимчасового трудового посвідчення для буржуазії, що фактично означало паспортизацію населення. В Україні така система була уведена в грудні 1919 р. після поразки денікінських військ. Зокрема, VIII конференція РКП(б) (2-4 грудня 1919 р.), розглядаючи питання про радянську владу в Україні, відновила політику “воєнного комунізму”, що означало мілітаризацію економіки, загальну трудову повинність та трудові мобілізації. А для контролю та примусу тих, хто не бажає працювати, так званих "трудових дезертирів", було введено “трудове посвідчення”.

3 вимушеною відмовою від попередньої політики "воєнного комунізму”, яка призвела до господарської розрухи та масового невдоволення усіх верств суспільства (у тому числі пролетаріату, який чомусь жодним чином не хотів працювати безкоштовно. Більше того, виявилося, що робітникам необхідна їжа, одяг та житло, а не тільки духовна їжа в вигляді “духа комунізму”), більшовицькі лідери змушені були прийняти НЕП. Це означало відмову від цілковитого контролю над населенням. Так, 1923 р. 
постановою “Про посвідчення особи”, в якому зазначалось прізвище, ім'я, по батькові, дата народження, місце проживання, професія, сімейний стан, наявність дітей та дані про військову службу, зняли всі обмеження на право пересуватися й проживати та заборонили вимагати від громадян обов'язкового пред'явлення паспортів та інших довідок на проживання. Та й отримувати “посвідчення особи” було необов'язково.

Однак, уже 1925 р. ухвалюється нове рішення - "Про прописку громадян у міських поселеннях", яка надавалася після пред'явлення будь-якого посвідчення особи: партійного або профспілкового квитка, виписки про народження та ін. та вводила реєстрацію за місцем проживання. 1927 р. нова постанова ВЦВК і РНК прив'язала громадян до місця роботи і проживання та передбачала особисті посвідчення, в яких обов'язковою графою була прописка. Наступним кроком стала постанова “Про встановлення єдиної паспортної системи по Союзу РСР і обов’язкову приписку паспортів" від 27 грудня 1932 р.

Такі кроки були спричинені зміною політики. Зокрема, того ж таки 1925 року XIV з'їзд ВКП(б) проголосив індустріалізацію. Переключилася на пропаганду політики індустріалізації й радянська пропагандистська машина, яка обіцяла уже через п’ять років забезпечити стрімке зростання народного добробуту. Однак, поділ промисловості на групи “А” і “Б” свідчив про першочерговий розвиток воєнно-промислового комплексу та галузей, що його обслуговували. 3 часом стало очевидно, що індустріальна гонка призвела до зниження життєвого рівня населення, а обраний курс не буде тимчасовим (відоме прислів'я часів СРСР - “нема нічого постійнішого, ніж тимчасові труднощі").

Будівництво “загального добробуту" не могло обійтися як без рабів, так і без наглядачів. Тому, аби трудящі раптом не передумали будувати комунізм, були створені мобілізаційні осередки на підприємствах і відповідні органи в управлінських структурах, які здійснювали функцію контролю над робітниками. А незгодних із високими темпами індустріалізації звинувачували в опортунізмі та шкідництві. Караючим мечем для інакомислячих стала Всеукраїнська надзвичайна комісія, яка 
звинувачувала в “шкідництві” всіх, хто виступав проти нереальних планових показників. Загальновживаними в офіційних документах стали заклики про необхідність нещадного викорінення “опортунізму”. Були організовані справи про “шкідництво” та показові судові процеси (наприклад, шахтинська справа 1928 р. проти інженерів Донбасу). Розпочалося організоване цькування фахівців з дореволюційними дипломами. Був уведений навіть спеціальний термін - “спецежерство”, створювалася атмосфера психозу, пов'язана з викриттям “шкідників".

Ще гіршою була ситуація в сільській місцевості, адже паспорти отримали лише мешканці міст, робітничих поселень та працівники радгоспів, яких прирівняли до держслужбовців. Натомість на більшість населення країни, яку становили селяни, паспортна система не розповсюджувалася. На них поширилося кріпацтво, бо як інакше можна назвати обов'язкове прикріплення до колгоспів (з 16 років) без права виїхати далі райцентру. Самовільний виїзд, без відповідної довідки від колгоспного керівництва, карався штрафом, а за повторне порушення можна було потрапити до в'язниці. “Світле майбутнє” у селах будувалося у вигляді примусової колективізації, трудоднів та бідності попри тяжку працю. Це спричинило опір, який найчастіше відбувався у формі “волинок” (демонстративному небажанні працювати в колгоспі - звідси ще одне радянське поняття "проволинити”) та “баб”ячих бунтів”. Спалахнули й збройні повстання, розмах яких викликав панічні настрої в керівних колах ВКП(б) та змусив проголосити свободу виходу селян із колгоспів, створених усупереч їхньої волі. Однак, після заспокоєння селян більшовицьке керівництво розпочало податковий тиск (замість адміністративного) та розкуркулення. I лише 1974 року прийняли “Положення про паспорти в СРСР", за яким паспорти отримували усі громадяни, які досягли 16 років. Таке рішення також диктувалося не турботою про селян, а необхідністю успішного виявлення антисуспільних елементів.

Руйнування національної ідентичності та насильницьке насадження більшовицького світобачення проходило й шляхом фізичного знищення селянства - організацією трьох голодоморів 1921-1923, 1932-1933 та 1946-1947 рр. 
Міф про турботу держави: “Жить стало лучше, жить стало веселей"

Міфологема нової комуністичної релігії знайшла своє відображення також у побуті та архітектурі. Провідні архітектори розробляли новітні прототипи будинків, орієнтовані на реалізацію міфу про колективізм, суспільне життя та побут - “дім-комуна", “житлокомбінат”, “будинок нового побуту", а влада популістично скасувала квартирну плату (Бузырев В., Чекалин В., 2001, с. 7). Заявивши про те, що “жовтнева революція, зруйнувавши гнилу будівлю царського самодержавства, грунтовно змінила всі підвалини нашого життя i на всю широчінь поставила питання культурного та побутового обслуговування трудящих, стираючи противенства в структурі міст і сіл, великих і малих міст, властиві капіталізмові" (Сустін 1932, с. 16), в реальності ж основним принципом існування радянських міст було, по-суті, будівництво величезного концтабору (ГУЛАГу). Уже 1932 р. визначалося, що “основою соціалістичного розселення $\epsilon$ велике соціалістичне виробництво, більш-менш рівномірно розміщене. Воно зумовлює й більш-менш рівномірне розселення людей по країні... Соціалістичні населені пункти, створені навколо вузлів соціалістичного виробництва, більш-менш рівномірно покривають всю країну, допускають лише таке скупчення, яке відповідає інтересам розвитку соціалістичних продуктивних сил" (Маркс и проблема... 1932, с. 1). Ідея полягала у тому, щоб спочатку побудувати підприємства там, де вони найкраще могли бути забезпечені сировиною, і лише потім “підвозилася" та заселялася необхідна кількість населення. Тож не дивно, що керівництво житловим фондом повністю перейшло до Всеукраїнської надзвичайної комісії. Нові відомства отримали право використовувати житло як засіб примусу до праці, дозволяючи виселення осіб, що належали до "нетрудових елементів", без надання їм іншого помешкання (Алфьоров М., 2009, с. 42-43).

Наслідком цього стає те, що переважна більшість населення, особливо у місцях будівництва індустріальних гігантів, поселялася у землянках, бараках, казармах або гуртожитках “на душу припадає “домовинна" норма, така кількість кубатури, 
що насилу можна за її наявності дихати"1 , там не було каналізації, води, а, подекуди, й електроенергії. Будівництво нового житла фактично не велося, а старі будинки, які не постраждали після воєн та революційних потрясінь, також не відповідали елементарним потребам і нормам, оскільки були перенаселеними внаслідок різних форм “ущільнення” квартир, тобто переселення пролетаріату до квартир заможних людей. Отже, владна ідея “нового соціалістичного гуртожитку” втілювалася в будівництві гуртожитків барачного типу та надання їх робітничому класу як передовій соціальній групі (Травин В., 2004, с. 25).

Життя тих щасливців, які врешті-решт отримували окреме житло в умовах тотального дефіциту та “нехватки” коштів, перетворювалося на забіг для його облаштування. Мізерної заробітної плати ледве вистачало на придбання харчів та одягу. А що вже говорити про купівлю побутових товарів, які були вкрай дефіцитними. "Сначала буду копить на холодильник, потом на телевизор”, - говорить героїня фільму у “благополучних" 1970-х роках, адже така “турбота радянської держави” була протягом усього існування СРСР.

Потребує уточнення й той факт, що придбати власне житло було неможливо. Людина, яка отримала житло від держави, не вважалася власником, адже все, що надане, за певних умов (критика державного устрою та навіть просто “немилість” партійних діячів) експропріювалося в дійсно неосяжні “закрома Родины”. I це було глобальною проблемою для молодих сімей. Черги на житло просувалися повільно, іноді до 20-30 років. З’явився новий прошарок соціальної піраміди, нижніх іiї рівнів, який в народі іменували “ліміта" - перспективна молодь, яка могла і мала бажання щось змінити у своєму житті, але “квартирный вопрос их испортил” 3 та інколи був нездоланною перепоною на шляху до реалізації мрії.

${ }^{1}$ Итоги сплошной подворной переписи Донецкой губернии (янв.-февр. 1923 г.). Том второй. Итоги городской переписи. Харьков, 1923. С. 29

${ }^{2}$ «Москва слезам не верит». Реж. В. Меншов. 1979 р. (Фільм отримав премію Оскар номінації «найкращий фільм іноземною мовою»).

${ }^{3}$ Булгаков М. Мастер и Маргарита. 
Більшовицька соціальна політика також опиралася на штучний перерозподіл благ. Так, першочергово надавалося житло та робота найнижчим соціальним групам, наприклад, повіям (Лебина Н., Романов П., Ярская-Смирнова Е., 2007, с. 37), а основною ознакою соціальної неповноцінності ставав минулий суспільний статус.

Варто сказати й про зовнішній вигляд та можливість відпочинку населення. Пересічний громадянин був вимушений носити одяг, вироблений радянською легкою промисловістю. Попри високу ціну, одяг вирізнявся низькою якістю, невеликим діапазоном розмірів (часто потрібно було “підганяти” придбаний одяг у ательє), відсутністю будь-якої індивідуальності та дизайнерських прикрас, - все це було радянською реальністю. Просто, некрасиво, незручно, але так практично - гасло легкої промисловості того часу, адже основне заняття трудящих мас важка праця задля "всеобщего блага”. Тому не одяг, а уніформа. Наприклад, шкільна форма депресивного, проте такого практичного, коричневого кольору для хлопців та дівчат, єдиного визначеного і схваленого зверху фасону.

Особливу увагу привертає той факт, що окрім важких побутових умов існування звичайне населення не мало навіть можливості на особистий відпочинок за власним вибором. Такі буденні для сучасних людей речі, як чашка кави у кафе, поїздка у інше місто, відвідування кіно, театру, концерту улюбленої музичної групи, для більшості населення того часу були неможливими. Згадаймо хоча б фрагмент із легендарного фільму “Місце зустрічі змінити не можна” про повоєнний період: Шарапов очікує Фокса в ресторані “Асторія”, п'є каву і нічого більше не замовляє, бо елементарно не має грошей ${ }^{1}$, і як закономірність - нахабство і зневажливе ставлення офіціантки, що, до речі, як раз й було нормою для радянського “общєпіта”.

Хоча радянська держава формально (показово) була країною всезагальної рівності ("молодым везде у нас дорога"), але за своєю сутністю мала чітко виражену кастову структуру. I якщо

${ }^{1}$ «Место встречи изменить нельзя» Реж. С. Говорухін, 1979 р. (знятий за романом братів Вайнерів «Ера милосердя»). 
сучасне українське суспільство має можливості реалізувати свій творчий потенціал, здобути вищу освіту, побудувати кар'єру, виїхати за кордон та й просто заробити собі на життя, то їхні попередники були позбавлені таких можливостей. Точніше, все залежало від класової приналежності (робітники, селяни, інтелігенція, буржуазія, дворянство та ін.), відданості “делу партии”, а головне - абсолютна готовність беззаперечно виконувати будь-які накази комуністичної партії (тут дійсно йдеться про будь-які дії - від зради і убивства до самопожертви), а згодом і від того, до якої касти належали батьки. Недаремно народний гумор поповнювався сумними жартами - “у генерала свій син $є$ ”, “скажи, хто твій тато, а я скажу, чи приймуть тебе” і т. д. I саме цей елітний прошарок партійної номенклатури, відібравши у дворянства, поміщиків, буржуазії та духовенства їхнє майно, жив у розкоші, саме задля його благ працювало населення усієї країни. I саме він дійсно жив при реальному, а не міфологічному (якуся інша частина країни) комунізмі. Представники вищої партійної касти, за рідкісним виключенням, могли дозволити собі поїздки за кордон, лікування в спеціальних лікарнях з найкращим медичним обладнанням і персоналом, спеціальні їдальні та ресторани, власний транспорт та житло, і навіть прислугу (відомий факт, що у вищого партійного керівництва була особиста прислуга, роботу якої оплачувала держава), а також отримання ексклюзивного одягу та інших товарів (до речі, дефіцит, ще одне поняття виключно радянської епохи) у спецмагазинах. Усе це вищій партійній еліті “полагалось вне очереди” задля того, щоб довести іноземцям високий рівень життя в “стране советов”.

Більше того, для партійних небожителів існувала навіть “своя” валюта - чеки Зовнішпосилторга. Ці “чарівні купони” можна було обміняти в спецмагазинах з великим вибором товарів (з ворожого "загниваючого Заходу") на продукти та товари. Пересічному громадянину навіть потрапити туди не було можливості ${ }^{1}$. Навіть забезпечення магазинів у середині країни було різним і поділялося на категорії. До першої належали столиці, у першу чергу, Москва та Ленінград. Там були продукти на вибір,

\footnotetext{
${ }^{1}$ Булгаков М. Мастер и Маргарита.
} 
а іноді з'являвся й імпорт, за яким відразу вишиковувалася величезна черга на півдня. Але вони були! Пов'язане це не лише з тим, щоб виховати у мешканців столиць відчуття своєрідної "елітарності" та “зверхності" над усіма іншими та привабленням найкращих "мізків" з безкрайнього простору СРСР, скільки з елементарним окозамилюванням та показом “забезпеченого” життя. Адже саме до Москви та Ленінграда, у першу чергу, приїздили іноземні туристи. Усі ж інші (а це переважна більшість населення) забезпечувалися вкрай погано. Наприклад, політолог та журналіст Віктор Каспрук згадує, що 1981 р. в глибинці на Черкащині намагалися купити хліб, на що продавчиня “зажурено сказала, що хліба не завозили вже три дні. Однак, в асортименті магазину були карамелі-подушечки, тюлька з душком, дешеве плодово-ягідне вино (ціна - 1 карбованець 02 копійки за пляшку), лимонад і сітро” (Каспрук В., 2016). Тож для простого населення існувала інша реальність - без Карлових Вар, італійського взуття, чорної ікри та грузинського вина, але декларувалося, що увесь радянський народ живе у достатку і добробуті.

Увесь трагізм долі більшості населення СРСР полягав саме у постійному пристосуванні, навіть більше - вихованні таких якостей, які давали можливість забезпечити себе і свою сім'ю елементарним: тим, що в цивілізованих країнах сприймається буденним - безліч рейсів у різних напрямках у межах міста, країни, світу; різноманітність товарів, їх варіативна складова; конкурентоспроможність на ринку надання послуг та обслуговування (продавці, сантехніки, перукарі і т. д.). Все це за часів радянської дійсності забирало безліч часу, нервів та здоров'я пересічного громадянина.

Однак, за вказівками партійної номенклатури радянські митці зобов'язані були виховувати новий, суттєво відмінний від попереднього, вид "homo soveticus" - людину радянську, людину країни Рад. Для цього потрібні були прототипи-герої, адже ніщо не виховує краще, ніж приклад реального (чи об'явленого таким) героя. (Все за традицією: небожителі, віра в дива, мученики і герої). Такими героями, за більшовицькою міфотворчістю, могли стати лише свої, звичайні радянські громадяни. I вони наділялися такими рисами: 
- класова ненависть до ворогів (зазвичай до тих, на кого вкаже партія);

- безмежна віра в мудрість влади (читаймо, влада комуністично-партійно-номенклатурна);

- відданість безпосередньо вождю (“за Леніна!”, “за Сталіна!”) та комуністичним ідеалам, що доходила до жертовності. Наприклад, коли діти "ворогів народу" відмовлялися від батьків і навпаки

- надлюдською працездатністю та готовністю терпіти негаразди заради “високої мети” (будівництво Дніпрогесу, Каховської ГЕС і т. д.)

Вдале маніпулювання свідомістю призводило до того, що населення переймалося не існуючими (реальними) проблемами - безправ'ям перед партійною номенклатурою та міліцією, обов'язковим виконанням понаднормових та понадурочних робіт (суботники, недільники і т. д.), тотальним дефіцитом, постійним підлещуванням не лише перед представниками влади, а й навіть перед робітниками у сфері обслуговування, а глобальними проблемами страйкуючих іспанців, афроамериканців, шахтарів Англії, Німеччини, індіанців Латинської Америки і т. д.

Наголосимо, що й на сьогодні “залишається величезний ідеологічний тиск радянсько-російської історичної спадщини, який можна пояснити передусім повною відсутністю української національної гуманітарної політики, а також мінімальною присутністю української історіографії та історії в світовій історичній думці" (Зашкільняк Л., 2015, с. 29).

Отже, нав'язування більшовиками нової ілюзорної системи світосприйняття було засноване на тому, що усім, без винятку, проблемам надавався статус пережитків тяжкої спадщини минулого - царизму, капіталізму, християнства і т. д. (читай - попередньої влади, попередників). 3 цією метою панівним класом було проголошено пролетаріат, який не мав освіти, був абсолютно відданий проголошеним ідеалам, сповідував ідею "відібрати та поділити” та вірив в обіцянки швидкого успіху. Усі ж інші верстви населення (якщо не були фізично знищені) відсувалися на

\footnotetext{
${ }^{1}$ Яновський Ю. Подвійне коло.
} 
другий план. Для подолання “пережитків минулого” та будівництва “щасливого майбутнього” створювалися нові механізми регулювання, які охоплювали всі сфери суспільного та особистого життя: створення нової релігії - “комунізму” з відповідним пантеоном богів, святих, героїв, храмів та нових свят, утвердження монополії офіційної ідеології та створення органів цензури, цілковитий контроль усіх без винятку громадських організацій i, звичайно, виховання відповідним чином дітей. Отже, відбувався своєрідний генетичний відбір. У населення формувався страх та беззахисність перед представниками влади, інертність та безвідповідальність, невміння відстоювати свої права та свободи та ін.

Наслідком цього стало те, що радянський менталітет виробив у людини своєрідну любов до бідності і негативне ставлення до багатства. А звідси постає постійне зниження вартості своєї праці. А кому потрібна бідна людна? Своїй сім'ї, своїм родичам або друзям? Врешті-решт, суспільству або своїй країні? Звичайно, що ні. Бідні люди потрібні лише представникам реальної влади - тим, хто контролює економіку та фінансові потоки. Багаті, незалежні та вільні люди не потрібні. Людину поставили в абсолютну залежність від представника влади, адже будь-кого могли легко перетворити на безхатька або жебрака. При цьому розподіляли зароблене цією ж людиною у власних інтересах та створювали міф про те, що держава надає населенню блага безкоштовно. Безкоштовна медицина, безкоштовна освіта, безкоштовне отримання житла та ін., що надає влада, - все це міфи радянської пропаганди, які сформували рабську психологію залежності людини від держави, що відбилася у світобаченні, яке існує і понині. Якби громадяни отримували заробітну плату відповідно до рівня країн “загниваючого” капіталізму, усіх цих подачок було б не потрібно, адже людина легко могла б самостійно забезпечити собі пристойне життя. Однак, більшовицька політика щодо населення була спрямована на повний контроль, диктат та навіть прямий терор. 


\section{Література}

Борисенко М.В. Дозвілля міського мешканця України в добу сталінізму. Педагогічні та рекреаційні технології в сучасній індустрії дозвілля : матеріали Міжн. наук.-практ. конф., 4-6 черв. 2004 р. / укл.: В. В. Кірсанов, С.Д. Безклубенко ; М-во освіти і науки України, М-во культури і мистецтв України, КНУКіМ. Київ : КНУКіМ, 2004. Ч. 1. С. 61-63.

Зашкільняк Л. Радянські історичні міфи в сучасній українській історіографії: "старе вино в нових міхах" / Л. Зашкільняк. Світло й тіні української радянської історіографії : матеріали міжнародної наукової конференції (Київ, Україна, 22-23 травня 2013 р.) / за ред В. А. Смолія. Київ, 2015. С. 21.

Попович М. В. Нарис історії культури України. Київ, 1998. 624 с.

Попович М. Міфологія в сучасній свідомості посткомуністичної України. Дух і літера. № 3-4. 1998. С. 57-68.

Молдавська Т. Радянська ідентичність та її вплив на формування сучасних суспільних стереотипів людей похилого віку (за матеріалами усноісторичних джерел Півдня України). Наукові записки Національного університету “Острозька академія". Серія: Культурологія. Острог, 2013. Вип. 12(2). С. 38-48.

Нікітенко К. Культура і суспільство: конфлікт між тоталітарним і особистим (на прикладі доби сталінізму). Вісник ЛНАМ. Серія: Культурологія. Вип. 29, 2016. С. 14.

Буряк Л.І. Моделі національної пам'яті в українській історіографії 1920-х років: пошук компромісу та спроби адаптації / Національна та історична пам'ять. Збірник наукових праць. Київ 2012. Вип. 5. С. 3-14.

Зашкільняк Л. Радянські історичні міфи в сучасній українській історіографії: "старе вино в нових міхах" / Л. Зашкільняк. Світло й тіні української радянської історіографії : матеріали міжнародної наукової конференції (Київ, Україна, 22-23 травня 2013 р.) / за ред В.А. Смолія. Київ, 2015. С. 17-31

Зашкільняк Л. Радянські міфи в сучасній українській історіографії: час змін і замін / Леонід Зашкільняк. Історія та історіографія в Європі. Київ, 2016. Вип. 5 : Україна в XX-XXI століттях: на шляху гідності і свободи. С. 103-117.

Кульчицький С. Як створювався лєнінсько-сталінський комуносоціалізм / Тиждень иа, 11 січня 2016. URL: https:/tyzhden.ua/ History/155673 
Гриневич В.А., Лисенко О.Є., Даниленко В.М., Кульчицький С.В. Радянський проєкт для України. Україна і Росія в історичній ретроспективі : нариси в 3-х т. Київ, 2004. Т. 2. Митрофаненко Ю. Робітники й селяни проти "робітничо селянської" влади. / Тиждень иа, 11 січня 2016. URL: https://tyzhden.ua/ History/155673;

Горенко О.М. Український метанаратив в епоху пропаганди. УІЖ. 2014. № 2. С. 4-21.

Маркс К. Классовая борьба во Франции с 1848 по 1850 годы / Маркс К. Энгельс Ф. Сочинения. Издание второе. Москва : Государственное издательство политической литературы, 1955. T. 7. С. 91.

Панин С. "Хозяин улиц городских": Хулиганство в Советской России в 1920-е годы. Вестник Евразии. 2003. № 4. С. 135-154.

Панин С. К вопросу о факторах активизации городского хулиганства в России в 20-е - начале 30-х гг. ХХ в. Известия Самарского научного центра Российской академии наук. Т. 11, № 6, 2009. C. 139-143.

Пора разобраться с хулиганами. Трудовая правда. 1926. 5 октября Культурне будівництво в Українській РСР. Важливіші рішення Комуністичної партії і радянського уряду 1917-1941 рр. : Зб. Документів Т. 1. (1917 - червень 1941 рр.). Київ,1959. С. 26.

“Чиж” и “Ёж”. Советские детские журналы 1920-х - середины 1930-х гг. Родина. 1 сентября 2015 год. URL: https:// rg.ru/2015/09/10/rodina-jurnaly.html

Бузырев В., Чекалин В. Экономика жилищной сферы. Москва : Ин-фра-М, 2001. С. 7.

Сустін Що таке Нове місто. Київ : ДВОУ Медвидав, 1932. С. 16. Маркс и проблема социалистического расселения / Советская Архитектура. № 2, 1932. С. 1.

Алфьоров М. Демографічний розвиток міст Східної України в 1920-1939 рр. / Схід. № 8 (99). Листопад 2009. С. 42-43 (40-44). Итоги сплошной подворной переписи Донецкой губернии (янв.-февр. 1923 г.). Том второй. Итоги городской переписи. Харьков, 1923. С. 29.

Травин В. Капитальный ремонт и реконструкция жилых и общественных зданий. Ростов н/Д : Феникс, 2004. С. 25.

Каспрук В. Міфи про щасливе життя в СРСР - гальмо для українського майбутнього. Paдіо свобода. 2016. 7 жовтня. URL: https://www.radiosvoboda.org/a/24729169.html 